\title{
狭盂部検査用連結型水中ビークルシステムの開発
}

\author{
岡田 聡* 小林 亮 介* 山本 広 志* 小 野 幸 彦*

\section{Development of Tandem Underwater Vehicle System for Narrow Section Inspection}

\author{
Satoshi Okada*, Ryosuke Kobayashi*, Hiroshi Yamamoto* and Yukihiko Ono*
}

\begin{abstract}
We have developed a new concept vehicle system for narrow section inspection of a nuclear power plant. We call this system as the tandem underwater vehicle system which consists of a small inspection ROV (Remotely Operated Vehicle), and support ROV which supports the inspection ROV moving. The support ROV needs the hovering control system which consists of detection sensors for a position and an attitude angle. In this system, the self position is detected by the light sectioning method and the image correlating method. As a result of evaluation examination, a position could be detected within $0.05[\mathrm{~m}]$ and an attitude angle could be detected with a less than 5-degree error. Moreover, in the conditions of water flow velocity $0.1[\mathrm{~m} / \mathrm{s}]$, it confirmed that it could hover less than $0.03[\mathrm{~m}]$ using the hovering controls function. As mentioned above, it was shown that a tandem underwater vehicle system is useful.
\end{abstract}

Key Words: Tandem, Vehicle, ROV, Inspection, Position, Attitude Angle, Hovering Control

\section{1.はじめに}

原子力発電所の炉内検査では, 目視検査（Visual Test：以下, VT）の後，必要に応じて超音波検查や渦電流検查を実施する ケースがある.VTでは, 検査箇所に応じて水中カメラや遠隔 操作ビークル (Remotely Operated Vehicle: 以下, ROV) [1] を用いるが, 炉底部等の狭盆部では, より小型の ROV が必要 となる。しかしながら，小型の ROVは，搭載可能なモータの 重量が制限されるため, 長いケーブルを旁引するための推進力 を持たせることが難しくなる. そこで, 本研究では, カメラを 搭載した小型の検査用 ROV と，その移動をサポートする支援 用 ROV からなる連結型ビークルシステムを検討した。連結型 の水中ビークルは, 海洋の分野において開発された実績はある が $[2]$, 開放空間での使用を前提としている. したがって，スラ スタや安定翼等を理想的な配置にできる反面，サイズが大きく なってしまうため, 寸法制約がある炉内への適用は困難と言え る.そこで，筆者らは炬内に適用可能な形状の連結型ビークル システムを検討した．また，支援用 ROV は，検査用 ROVを 切り離してから回収するまで, ケーブルをハンドリングしなが ら停留動作を行う。その際, 検査用 ROV の動作に影響を与え ないようにするために, 自己の位置変化を検知し, 一定の位置 に留まるための停留制御機能が必要になる，本報では，製作し たビークルシステムのハードウェアとしての成立性を評価した

原稿受付 2007 年 12 月 13 日

*(株) 日立製作所

${ }^{*}$ Hitachi Ltd.

ロ本論文は提案性で評価されました。
結果と，停留制御を実現するために必要な位置検知機能と制御 機能について, 検討および評価した結果について報告する.

\section{2. 連結型ビークルシステムの製作}

\section{1 システム構成}

ROV の形状は，使用環境に合せて設計する．Fig. 1 に，原 子炉の概略と, 今回開発した連結型ビークルシステムの適用イ メージを示す. Fig. 1 は，シュラウドサポート下部における狭湓 部のVTを行う例である．まず，二つの ROVを連結して潜航

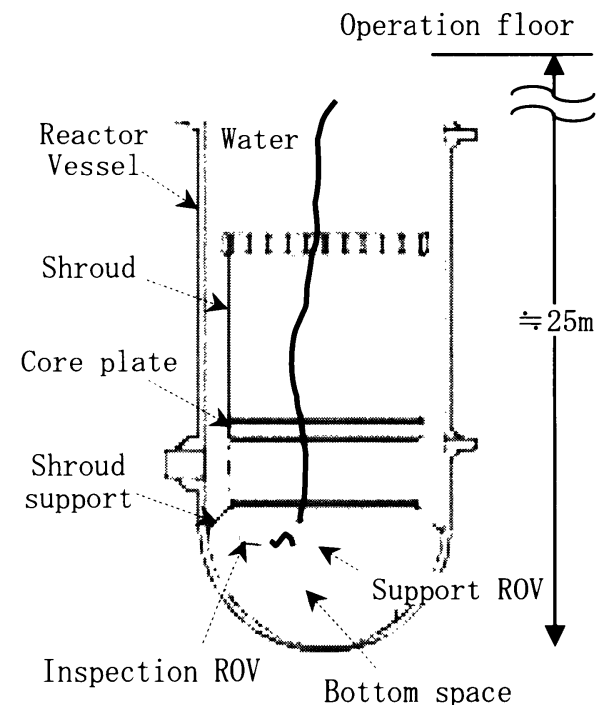

Fig. 1 Reactor and application image 
し, 炉底部付近で検査用 ROV を離脱させ, 狭险部にある検査 箇所に接近して検査に供する。支援用 ROV には, 検査用 ROV と接続するケーブルをハンドリングするためのウインチを設け てあり, 検査用 ROVにケーブルの引張力が掛らないように, 繰 出長を調整する。

\section{2 検査用 $\mathrm{ROV}$}

Fig. 2 に検査用 ROV の概略を示す. 検査用 ROV は, 三次 元的に移動するために, 前後進用の推進用スラスタと, 左右方 向変換用の旋回用スクリューと, ピッチ姿勢変換用のウエイト バランス調整機構の，三つのアクチュエータを内蔵している。ま た，前部には移動および VT 検査時に使用する, CCD カメラ と照明（LED）を搭載している。なお, CCD カメラの性能は, 原子炉内の VT で必要とされる性能, すなわち直径 $25[\mu \mathrm{m}]$ の ワイヤを視認できることを確認している。

\section{3 支援用 $\mathrm{ROV}$}

\section{3 .1 形状および推進機構}

Fig. 3 に，支援用 ROVの外観を示す. 2.1 節に示したように， 今回開発した ROV システムは, 炉底部付近まで支援用 ROV で潜航し, その後, 検査用 ROV を離脱させ, 狭险部に接近し て検査に供することを想定している。この際，制約寸法となる のは途中通過する炉心支持板 (Fig. 1 の Core plate) の円形孔 （直径 $270[\mathrm{~mm}]$ ）であるため, 支援用 ROV を直径 $250[\mathrm{~mm}]$ に 設計した。

さらに, 前方および後方には CCD カメラを搭載し, 移動時

Pitching control Mechanism

(Built in a weight balance adjustment)

CCD camera

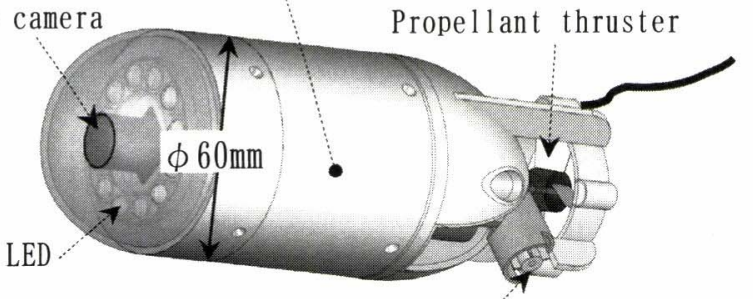

Gyrational screw

Fig. 2 Inspection vehicle



Fig. 3 Support vehicle
の視認および 2.3 .3 項で述べる自己位置検知機能を実現するた めに用いる。推進機構は, 昇降用スラス夕と, 水平移動用スラ スタの 2 種類のスラスタにより構成した. Fig. 4 に, 各スラス 夕の配置を示す。また, 水平移動用スラス夕は, 中央のウイン チを取り囲むように三つ配置し，水平面内の任意方向の移動お よび Yaw 回転に用いる.なお，三つの水平移動スラスタの回転 数は, 3.3 節で後述するべクトル制御により制御している.

\subsection{2 ウインチ}

支援用 ROV には, Fig. 3 に示すように, 検査用 ROV と接続 するケーブルをハンドリングするためのウインチを搭載してい る. そのケーブルには, 小型の検査用 ROV の航行を妨げない ように柔軟な中性浮力ケーブルを用いているため, ドラムと連 動したプーリにより強制的に引き出す機構を追加し, 円滑な動 作を実現している。 また, ケーブルは, 信号線であるため, ウイ ンチのドラム中心においては，固定極と回転極からなるスリッ プリングにより，信号を伝達している．

\section{3 .3 自己位置検知機能のためのセンサ構成}

支援用 ROVには, 検査用 ROV を離脱させた後, ケーブル をハンドリングしながら一定の位置に留まる停留制御機能が必 要となる。停留制御機能は, 第 3 章で詳述するように, 自己の 移動量および姿勢変化量を検知する位置検知機能と, その結果 からスラスタの動作量を決定する制御機能からなる.

位置検知機能のうち, 姿勢変化量は, Fig. 3 のセンサ室内に 設置した 3 軸ジャイロ，地磁気センサ，傾斜計により検出する. 一方，移動量は，スリットレーザ光源および CCD カメラを用 い, 光切断法 [3] [4] および画像相関法 [5]により算出する.

\section{4 動作確認}

Fig. 5 に，製作した連結型ビークルシステムを水中で動作さ せた際のサンプル画像を示す．Fig. 5 は，支援用 ROV から検 査用 ROV を離脱させた状態である。動作確認の結果，(1)支援

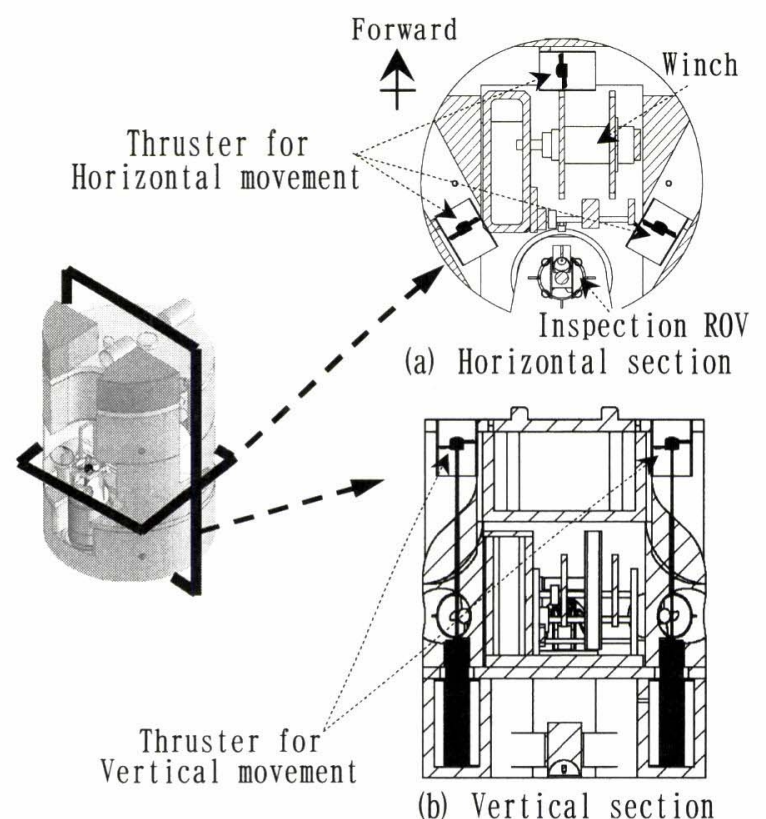

Fig. 4 Arrangement of thruster 


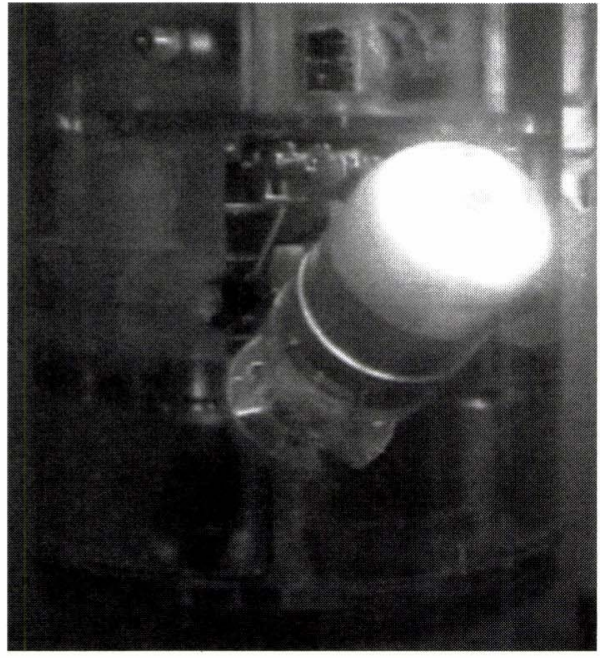

Fig. 5 Operation of tandem vehicle system

用 ROV は検査用 ROV を収納した状態で三次元的に移動でき ること, (2)支援用 ROV を停止させ検査用 $\mathrm{ROV}$ を離脱させる ことが可能であること, (3)支援用 ROV のウインチからケーブ ルを繰り出して検査用 ROV を進行させ水中において目視検査 が可能であること，を確認した。

\section{3. 停留制御機能}

\section{1 システム構成}

Fig. 6 に, 停留制御機能のシステム構成を示す.この構成で は, 停留制御開始時の支援用 ROV の位置·姿勢角を基準位置· 姿勢角とし, 搭載しているセンサとカメラの情報を用いて, 制 御装置内で現在の位置·姿勢角を算出する. その結果と, 基準位 置・姿勢角を比較演算し, 各スラスタの制御量を算出して, モー タへの指令電圧を決定する。このような一連の処理を, ROVの 状態が基準位置 ·姿勢角に達するまで繰り返し行い, 停留動作 を実現する。

なお，本開発における開発目標は，原子炉内構造物の寸法制 約により, 制御開始位置から $0.1[\mathrm{~m}]$ 以内に停留可能であること とした．また，この目標を達成するために, 位置は誤差 $0.05[\mathrm{~m}]$ 以内, 姿勢角は誤差 $5^{\circ}$ 以内での検知を目標とした.

\section{2 位置 - 姿勢角検知機能}

\section{2 .1 概要}

原子炉内は，構造物が多く超音波センサ等の外界センサを用 いた絶対位置検知方式は適用が困難であるため, 内界センサを 用いた慣性航法方式を検討した. Fig. 7 に, 位置検知機能の概 要を示す. 姿勢角 (Roll, Pitch, Yaw) は, ジャイロ, 傾斜計, 地磁気センサを用いて検出する。通常, 処理回路を持たない小 型のジャイロを用いて角度を算出する場合, 検出した角速度を 積分する際に発生する誤差が蓄積するという問題がある. そこ で, 本システムでは, カルマンフィルタ [6] を用いて最適值を推 定する方法を検討した. 一方, 位置についてはカメラ画像を処 理して算出する. 前後方向は, スリットレーザを用いた光切断 法, 左右・上下方向は, 画像相関法を用いて算出した速度から 求める構成とした.

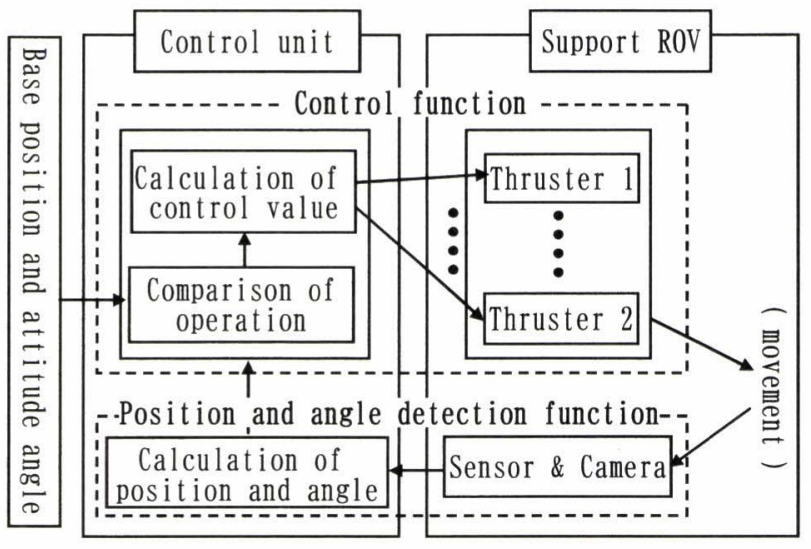

Fig. 6 Hovering control system

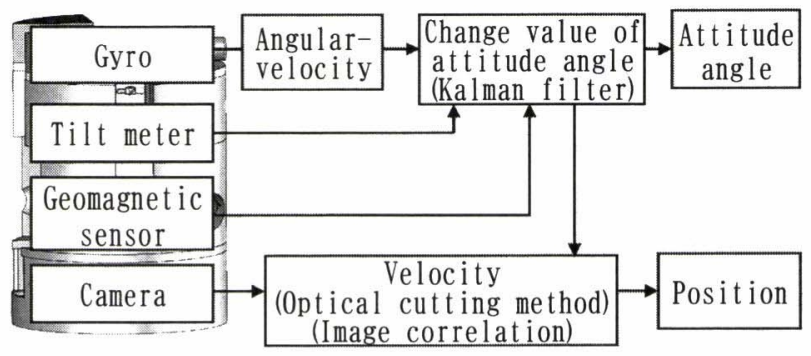

Fig. 7 Position and angle detection system



Fig. 8 Composition of Karman filter

\section{2 .2 姿勢角算出処理部}

Fig. 8 に, カルマンフィルタを用いた姿勢角処理部の構成を 示す. 本構成では, ジャイロ, 傾斜計, 地磁気センサの 3 種類の センサを用いて姿勢角を算出する。このうち, ジャイロは, 蓄積 誤差はあるものの，磁場環境の影響を受けず，また応答性も良 いことからメインのセンサとして用いる。，一方，傾斜計や地磁 気センサは，磁場の影響による系統誤差や，応答性が悪いとい う問題はあるが，蓄積誤差がないため, ジャイロの補正用セン サとして用いる。なお，地磁気センサはY Yaw，傾斜計は Roll， Pitch 検知用とした. Fig. 8 において，まず，ジャイロの検出 角速度に, 測定雑音を想定した雑音を重畳後, 積分して姿勢角 
を算出する. 次に, 算出した姿勢角と, あらかじめ設定してお いた補正用センサのモデルを用いて, 補正用センサの出力を推 定する。なお，補正用センサである傾斜計と地磁気センサのモ デルは, 角度一電圧換算係数であり, 各センサに固有の定数で ある. 次に, 各補正用センサで検出した実際の出力にも仮想の ノイズを重畳させ, 先に推定した補正用センサの出力との差分 を取る．この值が最小になるように姿勢角の修正を繰り返すこ とで, 姿勢角の最適值が出力されることになる. Fig. 9 に, 検 討した姿勢角算出処理部の性能を評価した結果を示す。試験は, 3 種類のセンサを搭載した評価ユニットを治具に固定し, Roll, Pitch, Yaw のそれぞれについて, $\pm 30^{\circ}$ 回転させたときの結果 である.この範囲において, 最大誤差 $5^{\circ}$ 以内で検知可能である ことが確認できた.

\section{2 .3 位置算出処理部}

前後方向の位置は, スリットレーザ光を当てた対象物の画像 を収録し，画像内のレーザ位置から対象物までの距離を測定す る光切断法を用いて算出する. Fig. 10 に，その原理を示す. カ メラと光軸を合わせ平行に設置したスリットレーザ光源から， 前方に水平スリットレーザを照射する．そのレーザ像を含む画 像を読み込み, 画像内の上下方向中心からの画素数 pic1 を求め る.ここで, レーザ光源とカメラの光軸の距離を $d$, カメラの 垂直視野角を $\beta$, 取り込み画像の上下方向の全画素数の半値を $p i c 2$ とし, 式（1）により対象物までの距離 $L$ を算出する. 距 離 $L$ の変化量を速度とし, 初期位置に加算して前後位置を算出 する.

$$
L=\left(d / \tan \frac{\beta}{2}\right) \cdot(p i c 2 / p i c 1)
$$

一方，上下左右の位置は，画像相関により算出する．Fig. 11 に, その原理を示す. まず, 時刻 $i-1$ において, 取得された画 像から, 画像相関に用いるテンプレートの切り出しを行う. 次 に, 時刻 $i$ において探索領域を切り出し, 相関処理を行い相関 值が最も大きくなるシフト量 $(\xi, \eta)$ を求める。このシフト量 と, カメラの水平画角 $\alpha$, 垂直画角 $\beta$, 取込画像の上下方向抒 よび左右方向の全画素数の半值 $p i c 2$ と $p i c 3$ を用いて, 式 (2) により左右および上下の速度 $\delta y, \delta z$ を算出し, 初期位置に積

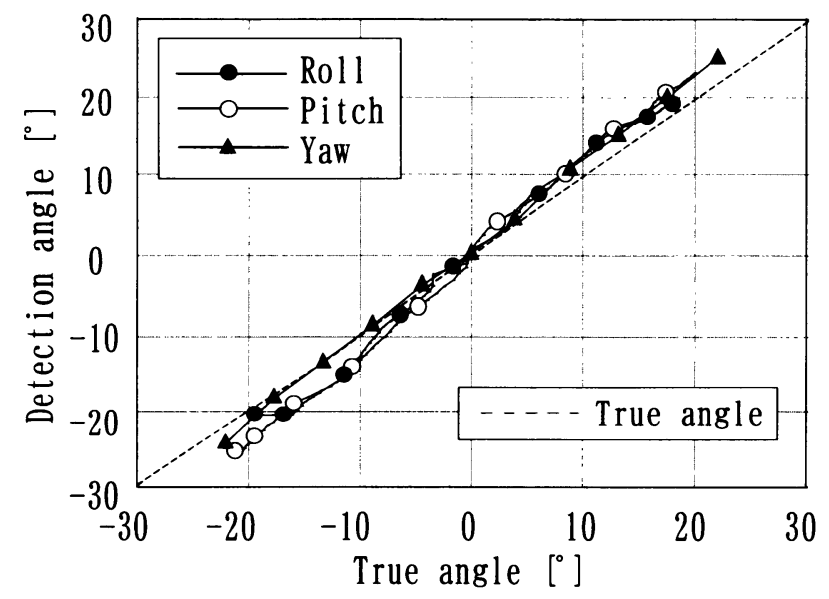

Fig. 9 Result of attitude angle detection
算して上下左右の位置を求める.

$$
\begin{aligned}
& \delta y=L \cdot \tan \frac{\alpha}{2} \cdot(\xi / p i c 3) \\
& \delta z=L \cdot \tan \frac{\beta}{2} \cdot(\eta / p i c 2)
\end{aligned}
$$

なお，式 $(2)$ より $\delta y ， \delta z$ を算出する際，前後距離 $L$ を用いるた め, 光切断法に用いるレーザ像がテンプレート内に含まれるよう にあらかじめ切り出し範囲を設定しておく. Fig. 12 に, 検討し た位置算出処理部の性能を評価した結果を示す．また，Fig. 13 に，評価試験におけるテンプレート画像の一例を示す。評価試

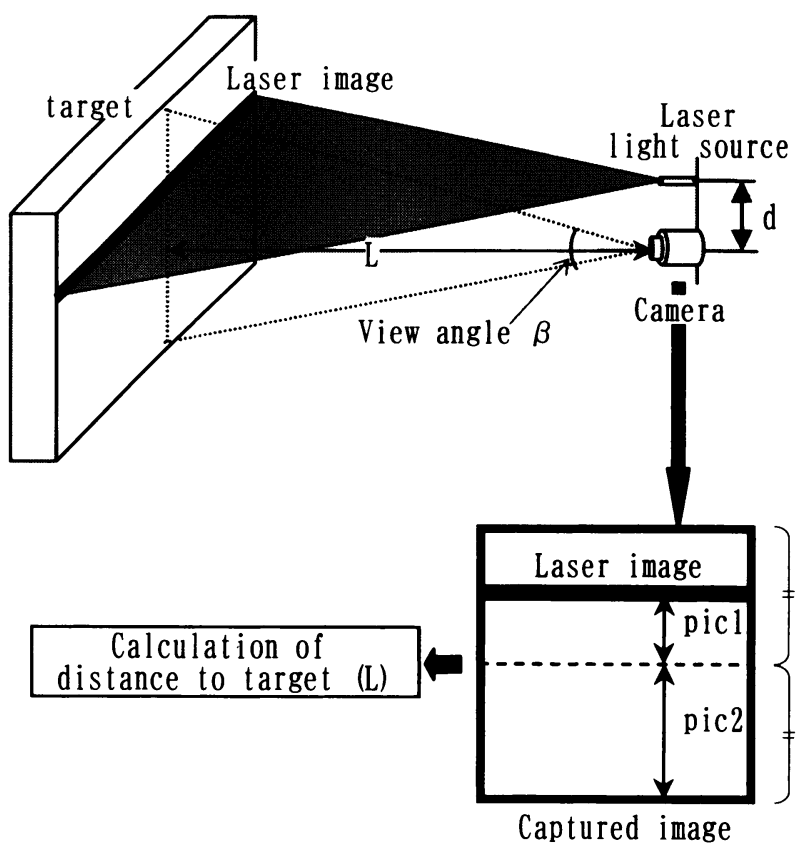

Fig. 10 Principle of light sectioning method

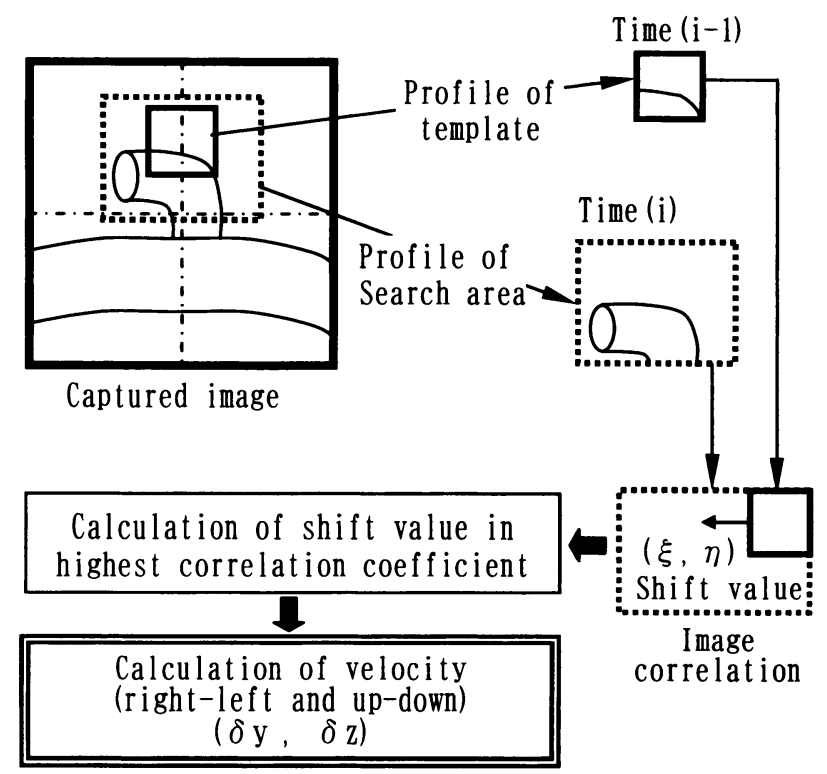

Fig. 11 Principle of right-left and up-down velocity by the image correlating method 


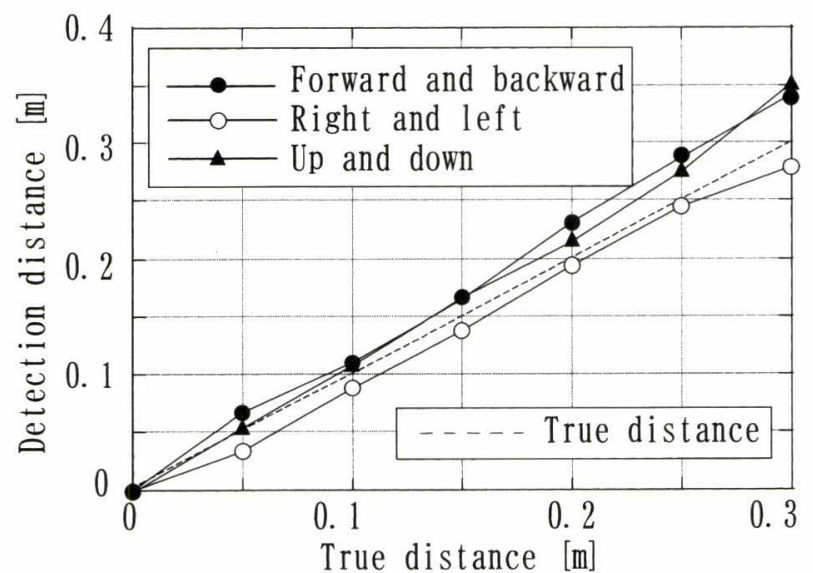

Fig. 12 Result of position detection

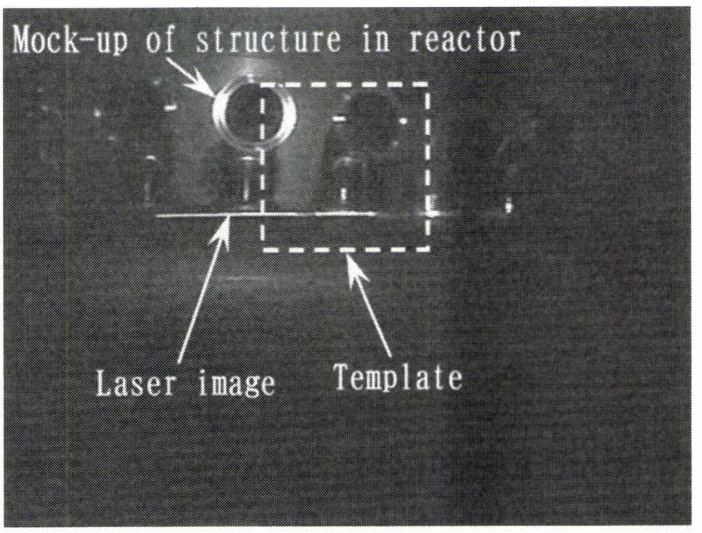

Fig. 13 Sample of captured image

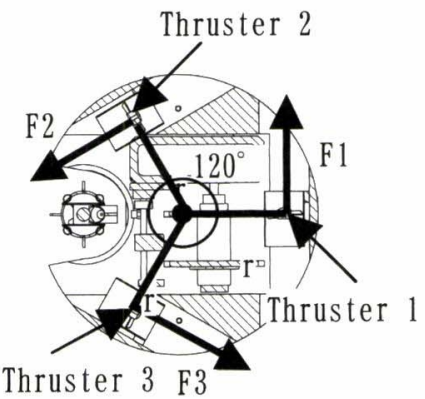

(a) Force of thrusters

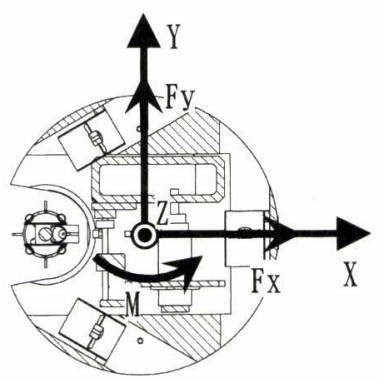

(b) Definition of force and moment
Fig. 14 Arrangement of horizontal thruster

験では，センサユニットの前方に原子炉内構造物のモックアッ プを設置し, 前後, 左右, 上下方向に, それぞれ $0.3[\mathrm{~m}]$ 移動さ せた. 評価の結果, 最大 $0.05[\mathrm{~m}]$ 以内で位置を検知可能である ことを確認した。

\section{3 制御機能}

\section{3 .1 ベクトル制御}

支援用 $\mathrm{ROV}$ を停留させる場合, 水平, 昇降, 旋回などの動作 を同時に行うため, 各スラス夕の推力を適切に制御する必要が ある.Fig. 14 (a) に各スラスタの配置, Fig. 14 (b) に力とモー メントの定義を示す.

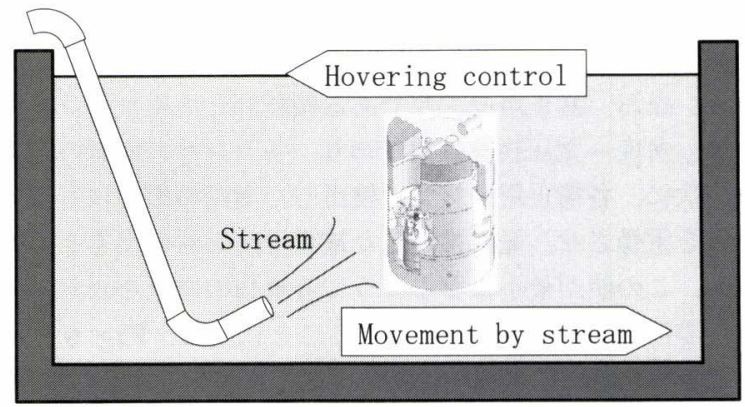

Fig. 15 Outline of evaluation test for hovering control system

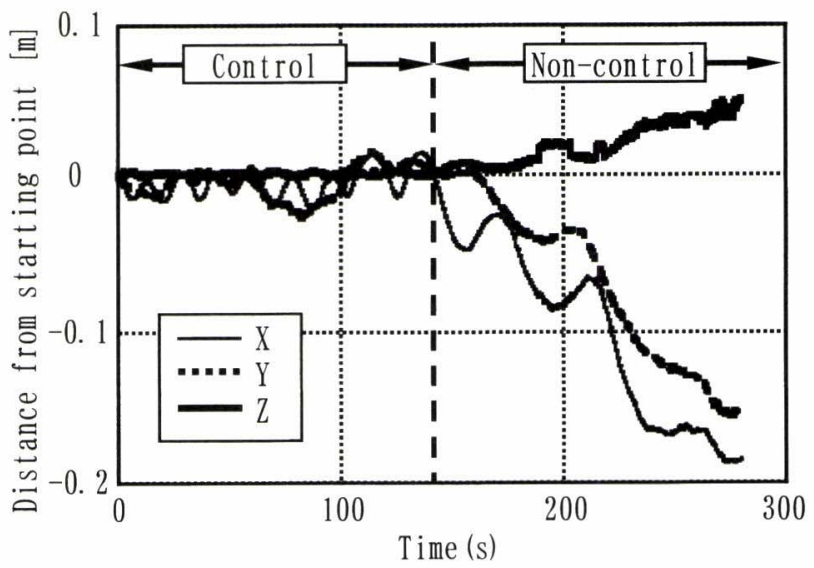

Fig. 16 Result of evaluation test

まず，昇降は他の動作とは独立しているため, 推力 $F_{z}$ を発 生させるには, Fig. 4(b) に示した二つの垂直移動用スラス夕 で，おのおの $F_{z} / 2$ ずつ発生させればよい. 水平移動と旋回は, 三つのスラスタへそれぞれ, 式 $(3)$ で算出される推力 $F_{1}, F_{2}$, $F_{3}$ を配分する.

$$
\left[\begin{array}{l}
F_{1} \\
F_{2} \\
F_{3}
\end{array}\right]=\left[\begin{array}{c}
0 \\
\frac{1}{\sqrt{3}} \\
-\frac{1}{\sqrt{3}}
\end{array}\right] F_{x}+\left[\begin{array}{c}
\frac{2}{3} \\
-\frac{1}{3} \\
-\frac{1}{3}
\end{array}\right] F_{y}+\left[\begin{array}{c}
\frac{1}{3 r} \\
\frac{1}{3 r} \\
\frac{1}{3 r}
\end{array}\right] M
$$

ここで, $F_{x}$ は前後方向に移動するための推力, $F_{y}$ は左右方向 へ移動するための推力， $M$ は鉛直下向きを正とする軸周りに発 生するモーメントである. 以上より, 基準位置・姿勢からの変 化量に応じて算出される指令推力を, 各スラス夕の制御量へと 変換することで, 停留動作が可能になる.

3.3 .2 停留制御機能の評価結果

Fig. 15 に, 停留制御機能の評価試験装置の概略を示す. 試験 では，支援用 ROV に噴霧ノズルを用いて拡散させた水流を当 て，停留制御機能の有無による動作の変化を評価した。ここで, 実機での流速は $0.04[\mathrm{~m} / \mathrm{s}]$ 程度であるため, 保守的な評価とな るように, ROVに当たる位置での流速を約 2 倍の約 $0.1[\mathrm{~m} / \mathrm{s}]$ に設定した。また，上下・左右・前後の全方向に対する停留動 作を評価するため, 水流は斜め下方から当てた. なお, 停留制 
御時は検査用 ROV を搭載しないため, 本試験でも搭載せずに 実施した。

Fig. 16 に結果を示す. Fig. 16 は, 横軸が経過時間, 縦軸が 開始時からの移動距離を示している. 各線は, Fig. 14 の $X, Y$, $Z$ に対応している. 試験では, 開始時点から停留制御を有効に し, 約 $140[\mathrm{~s}]$ 瑷に解除した. この結果より, 停留制御を有効に している間は, 停留目標の $0.1[\mathrm{~m}]$ 以内に対し, 最大 $0.03[\mathrm{~m}]$ 以内の範囲に停留できることが確認できた。 また, 制御を解除 すると, 水流に流されていることからも, 本機能の有効性が確 認できた。

\section{4.おわりに}

原子力発電プラントの狭鄎部検査用の連結型ビークルシステ ムを開発した。本システムは，狭隆部に進入し検査を実施する 検查用 ROV と，その航行を支援する支援用 ROV から構成し ている. 動作確認試験の結果, 支援用 ROV は検査用 ROV を 収納した状態で三次元的に移動できること, 支援用 ROV を停 止させ検查用 ROV を離脱させることが可能であること, 検査 用 ROV の動作に合わせてケーブル繰り出し長を調整でき, 水 中における目視検查が可能であることを確認した。

また, 支援用 ROV は, 検査用 ROV を切り離してから回収
するまで，ケーブルをハンドリングしながら停留動作を行うた め, 自己の位置および姿勢角の変化を検知し, 一定の位置に留 まるための停留制御機能が必要になる。位置は光切断法および 画像相関法により算出, 姿勢角は 3 種類のセンサの信号からカ ルマンフィルタを用いて算出する方式を開発した。評価試験の 結果, 位置は $0.05[\mathrm{~m}]$ 以内, 姿勢角は $5^{\circ}$ 以内の䛊差で検知でき ることを確認した，また，停留制御機能を用い，流速 $0.1[\mathrm{~m} / \mathrm{s}]$ の条件に扔いて，0.03 [m] の範囲内に停留できることを確認し た。以上から，連結型ビークルシステムが有用であることを示 した。なお，今後，実用化に向け，実機環境での評価試験を実 施する予定である.

\section{参 考 文 献}

[1] 鈴木正憲：“原子力発電プラント水中検查用 ROV の開発”, 日本口 ボット学会誌, vol.22, no.6, pp.697-701, 2004.

[ 2 ] 浦環, 高木真一: 海中ロボット. 成山堂書店, 1997.

[3] 近藤逸人, 卷俊宏, 浦環, 能勢義昭, 坂巻隆, 稲石正明: “自律型水 中ロボットによる構造物観測システム一光切断法を用いた測距システ ムによる相対航法—”, 日本機械学会ロボティクス・メカトロニクス 講演会'04 講演論文集, 2A1-L2-28, 2004.

[4] 岡田聡, 小林亮介, 山本広志: “原子炉狭價部検査用遊泳型 ROV の開 発”, 第 23 回日本ロボット学会学術講演会子稿集 CD-ROM, 2005.

[5] 徐剛, 过三郎: 3 次元ビジョン. 共立出版, 1998.

[6] 片山徹：応用カルマンフィル夕。朝倉書店, 1983 .

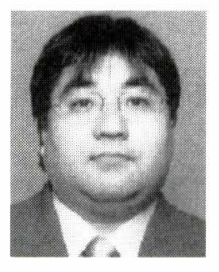

岡田 聡 (Satoshi Okada)

1993 年東北大学大学院工学研究科博士課程前期修 了. 同年（株）日立製作所に入社, 主として, 原子 力計装, 原子力検査技術, 空港の電気設備等に関す る研究に従事, 現在に至る。電気学会会員.

(日本ロボット学会正会員)

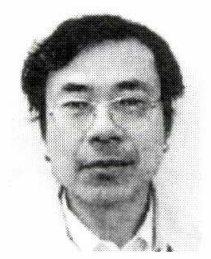

山本広志 (Hiroshi Yamamoto)

1971 年石川県立小松工業高等学校卒業, 同年 (株) 日立製作所機械研究所に入社, 主として, 移動口 ボット, 宇宙ロボットの研究に従事, 現在に至る. 日本機械学会会員.

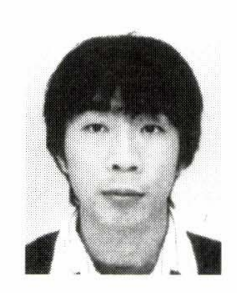

小林亮介 (Ryosuke Kobayashi)

2006 年東北大学大学院工学研究科博士課程前期修 了. 同年 (株) 日立製作所電力. 電機開発研究所に 入社, 原子炉内検査ロボットの研究に従事, 現在に 至る。

(日本ロボット学会正会員)

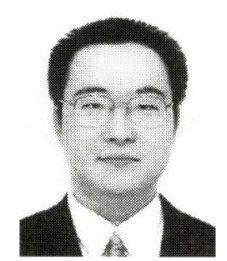

小野幸彦 (Yukihiko Ono)

2000 年東北大学大学院情報科学研究科システム情 報科学専攻博士課程前期修了. 同大学情報科学研究 科助手を経て, 2005 年（株）日立製作所機械研究 所に入社, 主として, 自律移動ロボットの研究に従 事, 現在に至る. IEEE 会員. 